\title{
Competencies and attributes needed by accounting graduates (alumni) in the world of work (perceptions of Politeknik Negeri Lampung accounting alumni and perceptions of the employer)
}

\author{
LRP Wijaya $^{{ }^{*}}$, D Pentiana ${ }^{1}$ and EY Puspitasari ${ }^{1}$ \\ ${ }^{1}$ Program Studi Akuntansi, Politeknik Negeri Lampung, Bandar Lampung, Indonesia \\ *Corresponding author: lihanwijaya@polinela.ac.id
}

\begin{abstract}
The objective of this research was to test perceptions of accounting graduates from Politeknik Negeri Lampung and employers to various competencies and their attributes. The perceptions of accounting graduates and employers were ranked to produce competence types (attributes) that were categorized into two skills; generic and technical skills. The research respondents were graduates of the Accounting Study program in Politeknik Negeri Lampung and representatives from employer or company managements. The hypothesis was tested with a one-tailed paired t-test and ranking was done based on the mean score from each skill. The research result showed that the accounting graduates considered generic skill was overall more important than technical skill, even though individually technical skill was more important than generic skill and it was proven by the highest mean score at technical skill according to the accounting graduates' perceptions. This research also found that overall the employer considered generic skill was more important than technical skill, even though individually technical skill obtained the highest mean score according to employer perceptions.
\end{abstract}

\section{Introduction}

The Era of Industrial Revolution 4.0 indirectly demands that the world of education produce graduates who have qualified competencies in the field in which they are in, one of the goals of humans in pursuing education is the ease of finding work, but it turns out that the higher the level of one's education is not a guarantee in getting a job faster. This can be seen from BPS data in February 2019 in Lampung Province where in terms of labor absorption until February 2019 it is still dominated by residents working with elementary education and below as many as 1,870.8 thousand people (44.19\%), junior high school as many as 907.8 thousand people (21.44\%), senior high school as many as 16.23 thousand people $(16.23 \%)$, and vocational high schools as many as 379.9 thousand people $(8.97 \%)$.

While the population working for Diploma I / II / II is as many as 101.9 thousand people $(2.41 \%)$ and those with undergraduate education are as many as 286.2 thousand people (6.76\%) (Figure 1) (BRS, 2019).

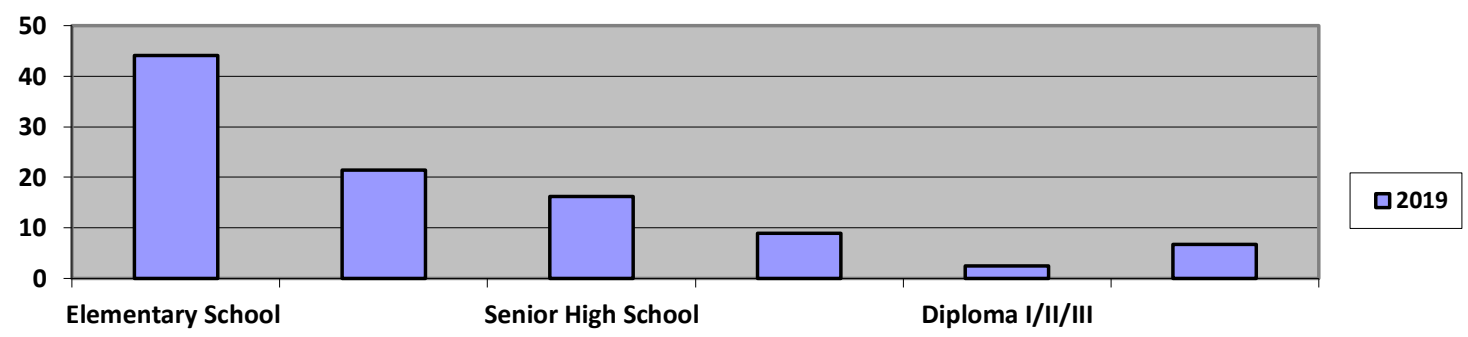

Figure 1. Percentage of Working Population according to Highest Education Enrolled in Lampung Province, February 2019 
Based on these data, in terms of education level, graduates with Diploma I / II / III education levels have the lowest employment rate of $2.41 \%$. This certainly raises the assumption that the gap between employers and graduates, including accounting graduates, still exists today (Utama, 2017).

This gap makes employers express their concern that the accounting program is not in line with the requirements of the accounting profession (Albrecht and Sack in Sithole (2015)). This gap should be broken down in line with the government's desire, in this case, the Ministry of Education and Culture, with an independent campus program, one of which is the independence of students to do internship/field practice / social service program outside of campus, including in industry or the real professional world so that they are ready to work.

Research conducted by Jackling and De Lange (2009) states that the ever-changing business environment requires someone skilled in various matters with special knowledge and expertise. Regarding the special skills that must be possessed, the competence of accounting graduates is very important to be considered by the campus world.

The competence of accounting graduates can be measured through competency standards that have been determined by the National Professional Certification Agency (BNSP) organized by the Professional Certification Institution (LSP)where the competencies tested are based on the National Competency Standards (SKKNI). SKKNI for Professional, Scientific, and Technical Service Categories for Accounting, Bookkeeping, and Auditor Services, Tax Consultants, Sub-Class Accounting Technicians that have been compiled and have received recognition by stakeholders will be beneficial if they are implemented consistently. The Work Competency Standards are used as a reference for Educational and Work Training Institutions, the Labor Market and the Business / Industry World as well as Labor Users (Decree of the Minister of Manpower and Transmigration RI No. 182, 2013)

The competence of Diploma III accounting graduates enters qualification III, namely Primary Accounting Technicians wherein the SKKNI the competency units that must be possessed by accounting graduates consist of applying professional practice principles at work, implementing health and safety practices in the workplace, processing journal entries, processing books large, compile financial reports, operate numeric processing packages (spreadsheets), operate accounting computer applications, manage accounts receivable cards, manage debit cards and manage inventory cards.

Accounting programs as providers of higher accounting education need to always be aware of the development of students and graduates along with their experiences and other relevant data. One of the important things to know is their perception of the skills and attributes they must have as capital to compete in the world job market. This is important for them as a reflection of the various skills and attributes that they must know and prepare (Kurniawan, 2017).

By using the pratama accounting technician competency instrument, this study conducted a test on the perceptions of alumni and employers of the types of competencies that are important to alumni and testing between competency categories of the attributes that make them up and ranking against these various competencies which are considered a priority both by alumni and employer.

This study aims to test empirically the perceptions of alumni and employers of various types of skills and attributes, this study also conducts rankings to conclude what types of skills/attributes are priorities so that alumni can play in the world of work and employers are satisfied with the knowledge and the skills brought by alumni. Testing was carried out on 41 attribute items which were classified into 10 types of competencies, these competencies were categorized into two skills, namely technical skills and generic skills.

\section{Competency of Accounting based on SKKNI}

Competence is defined as the ability needed to do or carry out work based on knowledge, skills, and work attitudes. So it can be formulated that competence is defined as the ability of a person who can be observed including knowledge, skills, and work attitudes in completing a job or task following established performance standards (Minister of Manpower and Transmigration Decree No. 182, 2013) 
The National Competency Standards (SKKNI) for professional, scientific, and technical service categories for accounting, bookkeeping, and auditing services, tax consultant sub-class accounting technicians that have been compiled and have received recognition by stakeholders will be beneficial if they are implemented consistently.

Law No. 13 of 2003 concerning Employment regulates that job training is held based on a training program that refers to work competency standards (Article 10). It is stated in the Law that the competence of the labor is formed from three domains, namely the realm of knowledge (cognitive), the realm of skills (psychomotor), and the realm of attitude (affective). Each of these three areas is related to the ability to think, the ability to move the limbs with certain methods or techniques, and the ability to express one's will. In summary, this competency is defined as the mastery of scientific disciplines and knowledge and skills in applying certain methods or techniques supported by appropriate behavioral attitudes to achieve and/or realize certain results in carrying out work tasks.

\section{Required Skills and Attributes}

Researchers have tried to distinguish between broader generic skills as opposed to specific technical and practical skills (Crebert, 2002; Ashbaugh dan Johnstone, 2000) and provide meaning to the attributes and skills as defined in the context of education and accounting work contexts (Holmes, 2001). Many authors internationally claim that the widening gap between education and practice in the world of work calls for changes to the curriculum (Bowden dan Masters, 1993; Crebbin, 1997; Wiggin, 1997; Yap, 1997; Albrecht dan Sack, 2000). In Spain and the UK, higher education has been revised to improve the quality of education and reduce the gap in expectations associated with employer demands (Hassell, et al, 2005). It can be concluded that accounting educators around the world have argued for changing curricula to create graduates with a broader set of skills and attributes than just technical accounting skills. (Braun, 2004). The compiled portfolio of accounting graduate skills includes a variety of knowledge and skills needed to answer the challenges of the world of work. Of course, technical skills are the main thing, especially in fields of knowledge that do require these skills such as accounting, finance, and corporate law. Technical skills enable professional accountants to carry out their jobs effectively and satisfy employers or clients. Referring to IES 3 "professional skills", accounting technical and functional skills consist of general skills and specific skills for accountants. These skills include: (a) numeracy (mathematics and statistical applications) and information technology skills, (b) decision modeling and risk analysis, (c) measurement, (d) reporting, (e) compliance with legislative and regulatory requirements. Furthermore, skills development in higher education accounting programs has been suggested to prepare accounting that is more flexible and adaptive to the continuing evolution of the labor market. This flexibility and adaptive attitude are not sufficient to be equipped with accounting technical skills alone. Many studies have found that there is a gap between education and practice in the world of work (Bowden and Masters, 1993; Albrecht and Sack,2000). The pressures of competition and technological evolution have led to expectations that demand that accounting graduates also need to be equipped with additional skills to take on these new challenges. Apart from technical skills, the business world seems to expect more generic skills such as personal, interpersonal, and intellectual qualities (Kavanagh dan Drennan, 2008).

Klibi and Oussi (2013) from their literature review imply that previous studies have often shown that these skills do not have equal weight in the accountant labor market. Technical competence is still considered a basic skill that must be possessed. However, De Lange et. al (2006) stated that technical competence is only needed more at the entry-level, but career success is more determined by "personal characteristics". Likewise, on the employer side, they seem to agree more than generic skills add more value to the company. Quoted from Klibi and Oussi (2013), to explain these findings, Hunton (2002) indicates that many traditional accounting jobs have become automatic, leading us to the claim that the value of a professional accountant today is more indicated by generic abilities. Even more so, many employers have considered technical skills, which are directly related to the accounting profession, as implicit and obvious. 


\section{Methods}

This research was conducted at the Politeknik Negeri Lampung accounting alumni who have worked and the employer (company) and the public accounting firm (KAP) where the alumni worked. The type of data used in this study is primary data, namely by interviewing and distributing questionnaires to target respondents, namely company managers and public accounting firms (KAP) and accounting graduates who work in companies and KAP

Respondents were asked to rank 41 skills/attributes on a scale from 1 (not priority) to 5 (top priority). Internal consistency of the questions was tested using Cronbach Alpha. To test hypotheses 1 and 2, a comparison is made between the overall mean score of the technical and generic skills of each group of respondents. Hypothesis testing is done using a one-tailed paired t-test.

Besides, to test the hypothesis, this study will rank the various skills and attributes to obtain an overview of the relative importance of these skills and attributes. The ranking is done by taking the mean data of each type of skill/attribute.

\section{Result of Research}

\subsection{Sample}

This study involved 93 respondents consisting of 61 accounting alumni who have worked and 32 employers, in this case, the management. Of the 93 respondents, there were 30 men and 63 women. Based on their work experience $76.34 \%$ of respondents have worked for less than 5 years, while $23.66 \%$ of the others have work experience over 5 years. The following are the characteristics of the research respondents in Table 1:

Table 1. Data of Characteristic of Respondents

\begin{tabular}{|c|c|c|}
\hline & Amount & Percentage (\%) \\
\hline \multicolumn{3}{|l|}{ Work Experience } \\
\hline less than 5 years & 71 & 76,34 \\
\hline $5-10$ years & 17 & 18,27 \\
\hline $10-15$ years & 4 & 4,30 \\
\hline more than 15 years & 1 & 1,07 \\
\hline \multicolumn{3}{|l|}{ Gender } \\
\hline men & 30 & 32,26 \\
\hline women & 63 & 67,74 \\
\hline
\end{tabular}

\subsection{Hypothesis Testing}

The first hypothesis proposed in this study is that it is predicted that technical skills alumni (X3, X4, $\mathrm{X} 5, \mathrm{X} 6, \mathrm{X} 7, \mathrm{X} 8, \mathrm{X} 9, \mathrm{X} 10)$ are more important than generic skills $(\mathrm{X} 1, \mathrm{X} 2)$. Whereas for the second hypothesis of this study is for employers' generic skills $(\mathrm{X} 1, \mathrm{X} 2)$ are more important than technical skills (X3, X4, X5, X6, X7, X8, X9, X10).

\subsubsection{Perception of Alumni}

The results of data processing for alumni perceptions of competencies that are considered important in the world of work are being able to follow health and safety procedures in the workplace to identify hazards and control risks, be able to enter data according to cell characteristics and data sources and be able to archive source documents and supporting documents promptly and following company policies and procedures. The highest attribute that is considered important is a generic skill, while the second and third attribute which is considered important by alumni is a technical skill. The following table presents the competency attributes that are considered important according to alumni perceptions based on the average rating (mean) (Table 2). 
Table 2. Result of Competency Attributes Ranking according to Alumni based on Mean

\begin{tabular}{|c|c|c|c|c|c|c|}
\hline Variable & $\mathbf{N}$ & Min & Max & Mean & $\begin{array}{c}\text { Std } \\
\text { Deviation }\end{array}$ & Variance \\
\hline $\mathrm{X} 2.1$ & 61 & 3 & 5 & 4,59016 & 0,55908 & 0,31257 \\
\hline X6.2 & 61 & 3 & 5 & 4,54098 & 0,56491 & 0,31913 \\
\hline X3.3 & 61 & 3 & 5 & 4,52459 & 0,53562 & 0,28689 \\
\hline $\mathrm{X} 1.3$ & 61 & 3 & 5 & 4,47541 & 0,53562 & 0,28689 \\
\hline $\mathrm{X} 4.2$ & 61 & 3 & 5 & 4,44262 & 0,61980 & 0,38415 \\
\hline X3.1 & 61 & 3 & 5 & 4,42623 & 0,56152 & 0,31530 \\
\hline X6.1 & 61 & 3 & 5 & 4,42623 & 0,61803 & 0,38197 \\
\hline X1.4 & 61 & 3 & 5 & 4,39344 & 0,58534 & 0,34262 \\
\hline $\mathrm{X} 4.3$ & 61 & 3 & 5 & 4,37705 & 0,61003 & 0,37213 \\
\hline $\mathrm{X} 2.3$ & 61 & 2 & 5 & 4,37705 & 0,66242 & 0,43880 \\
\hline X8.4 & 61 & 3 & 5 & 4,34426 & 0,62942 & 0,39617 \\
\hline $\mathrm{X} 4.1$ & 61 & 3 & 5 & 4,34426 & 0,60236 & 0,36284 \\
\hline X7.5 & 61 & 3 & 5 & 4,34426 & 0,62942 & 0,39617 \\
\hline X9.2 & 61 & 3 & 5 & 4,34426 & 0,68032 & 0,46284 \\
\hline X3.2 & 61 & 3 & 5 & 4,32787 & 0,65119 & 0,42404 \\
\hline X9.3 & 61 & 3 & 5 & 4,32787 & 0,65119 & 0,42404 \\
\hline $\mathrm{X} 1.2$ & 61 & 3 & 5 & 4,31148 & 0,59276 & 0,35137 \\
\hline X10.3 & 61 & 3 & 5 & 4,31148 & 0,64655 & 0,41803 \\
\hline X9.1 & 61 & 3 & 5 & 4,31148 & 0,64655 & 0,41803 \\
\hline X8.3 & 61 & 3 & 5 & 4,31148 & 0,62024 & 0,38470 \\
\hline X6.3 & 61 & 3 & 5 & 4,29508 & 0,58720 & 0,34481 \\
\hline X7.3 & 61 & 3 & 5 & 4,29508 & 0,58720 & 0,34481 \\
\hline X7.4 & 61 & 3 & 5 & 4,29508 & 0,64146 & 0,41148 \\
\hline $\mathrm{X} 10.2$ & 61 & 3 & 5 & 4,27869 & 0,60913 & 0,37104 \\
\hline $\mathrm{X} 2.2$ & 61 & 3 & 5 & 4,26230 & 0,62986 & 0,39672 \\
\hline X6.4 & 61 & 3 & 5 & 4,26230 & 0,65579 & 0,43005 \\
\hline X9.4 & 61 & 3 & 5 & 4,26230 & 0,70478 & 0,49672 \\
\hline X10.1 & 61 & 3 & 5 & 4,26230 & 0,62986 & 0,39672 \\
\hline $\mathrm{X} 1.5$ & 61 & 3 & 5 & 4,24590 & 0,59598 & 0,35519 \\
\hline X8.2 & 61 & 3 & 5 & 4,24590 & 0,64951 & 0,42186 \\
\hline X7.2 & 61 & 3 & 5 & 4,22951 & 0,61626 & 0,37978 \\
\hline X8.1 & 61 & 3 & 5 & 4,22951 & 0,58860 & 0,34645 \\
\hline X10.5 & 61 & 3 & 5 & 4,21311 & 0,66118 & 0,43716 \\
\hline X8.5 & 61 & 3 & 5 & 4,21311 & 0,63547 & 0,40383 \\
\hline X5.4 & 61 & 3 & 5 & 4,19672 & 0,70284 & 0,49399 \\
\hline X10.4 & 61 & 3 & 5 & 4,18033 & 0,64571 & 0,41694 \\
\hline X1.1 & 61 & 3 & 5 & 4,16393 & 0,58253 & 0,33934 \\
\hline X5.3 & 61 & 3 & 5 & 4,16393 & 0,68752 & 0,47268 \\
\hline X7.1 & 61 & 3 & 5 & 4,13115 & 0,67021 & 0,44918 \\
\hline X5.1 & 61 & 3 & 5 & 4,08197 & 0,64018 & 0,40984 \\
\hline X5.2 & 61 & 3 & 5 & 4,04918 & 0,58953 & 0,34754 \\
\hline
\end{tabular}

Based on the skill category, the order of importance can be seen in the table below: 
Table 3. Result of Skills Ranking according to Alumni based on Mean

\begin{tabular}{llr}
\hline Variable & Skill Category & Mean \\
\hline X3 & Technical skills & 4,43169 \\
X2 & Generic skills & 4,40984 \\
X4 & Technical skills & 4,38798 \\
X6 & Technical skills & 4,38115 \\
X1 & Generic skills & 4,31803 \\
X9 & Technical skills & 4,31148 \\
X8 & Technical skills & 4,26885 \\
X7 & Technical skills & 4,25902 \\
X10 & Technical skills & 4,24918 \\
X5 & Technical skills & 4,12295 \\
\hline
\end{tabular}

The mean for all generic skills is 4.352 while the mean for technical skills is 4.291 based on these results, it can be seen that the average alumni perceive that generic skills are more important than technical skills, this is supported by a significance value $(t=1.347$ and $\mathrm{sig}=0.006)$. Thus, hypothesis 1 failed to be supported. These results indicate that the results of the study are contrary to hypothesis 1 which states that alumni consider technical skills more important than technical skills, however, in terms of the highest average ranking of the skills category, it is found that technical skills are still the highest skills considered important by alumni at 4,431.

\subsubsection{Perception of Employer}

Table 4. Result of Competency Attributes Ranking according to Employer based on Mean

\begin{tabular}{lllllcc}
\hline Variable & N & Min & Max & Mean & Std. Deviation & Variance \\
\hline X1.2 & 32 & 3,00 & 5,00 & 4,6250 & 0,55358 & 0,306 \\
X2.2 & 32 & 3,00 & 5,00 & 4,5938 & 0,55992 & 0,314 \\
X9.3 & 32 & 3,00 & 5,00 & 4,5313 & 0,67127 & 0,451 \\
X6.1 & 32 & 3,00 & 5,00 & 4,5000 & 0,62217 & 0,387 \\
X2.1 & 32 & 3,00 & 5,00 & 4,4688 & 0,62136 & 0,386 \\
X3.3 & 32 & 3,00 & 5,00 & 4,4375 & 0,61892 & 0,383 \\
X8.3 & 32 & 3,00 & 5,00 & 4,4375 & 0,61892 & 0,383 \\
X4.1 & 32 & 3,00 & 5,00 & 4,4063 & 0,66524 & 0,443 \\
X4.3 & 32 & 3,00 & 5,00 & 4,4063 & 0,61484 & 0,378 \\
X6.4 & 3,00 & 5,00 & 4,4063 & 0,61484 & 0,378 \\
X7.3 & 32 & 3,00 & 5,00 & 4,4063 & 0,55992 & 0,314 \\
X8.4 & 32 & 3,00 & 5,00 & 4,4063 & 0,66524 & 0,443 \\
X8.1 & 32 & 3,00 & 5,00 & 4,3750 & 0,65991 & 0,435 \\
X7.5 & 32 & 3,00 & 5,00 & 4,3750 & 0,60907 & 0,371 \\
X9.2 & 32 & 3,00 & 5,00 & 4,3750 & 0,75134 & 0,565 \\
X2.3 & 32 & 3,00 & 5,00 & 4,3750 & 0,65991 & 0,435 \\
X1.4 & 32 & 3,00 & 5,00 & 4,3438 & 0,65300 & 0,426 \\
X10.3 & 32 & 3,00 & 5,00 & 4,3438 & 0,70066 & 0,491 \\
X9.1 & 32 & 3,00 & 5,00 & 4,3438 & 0,70066 & 0,491 \\
X3.1 & 32 & 3,00 & 5,00 & 4,3125 & 0,64446 & 0,415 \\
X8.2 & 32 & 3,00 & 5,00 & 4,3125 & 0,69270 & 0,480 \\
\hline & 32 & & & &
\end{tabular}




\begin{tabular}{lllllll}
\hline X8.5 & 32 & 3,00 & 5,00 & 4,3125 & 0,69270 & 0,480 \\
X1.3 & 32 & 3,00 & 5,00 & 4,3125 & 0,69270 & 0,480 \\
X9.4 & 32 & 3,00 & 5,00 & 4,3125 & 0,73780 & 0,544 \\
X7.2 & 32 & 3,00 & 5,00 & 4,2813 & 0,63421 & 0,402 \\
X10.2 & 32 & 3,00 & 5,00 & 4,2813 & 0,63421 & 0,402 \\
X1.1 & 32 & 3,00 & 5,00 & 4,2813 & 0,52267 & 0,273 \\
X6.2 & 32 & 3,00 & 5,00 & 4,2813 & 0,63421 & 0,402 \\
X7.1 & 32 & 3,00 & 5,00 & 4,2813 & 0,63421 & 0,402 \\
X10.1 & 32 & 3,00 & 5,00 & 4,2813 & 0,68318 & 0,467 \\
X1.5 & 32 & 3,00 & 5,00 & 4,2500 & 0,56796 & 0,323 \\
X3.2 & 32 & 3,00 & 5,00 & 4,2500 & 0,62217 & 0,387 \\
X5.3 & 32 & 3,00 & 5,00 & 4,2500 & 0,67202 & 0,452 \\
X4.2 & 32 & 3,00 & 5,00 & 4,2500 & 0,62217 & 0,387 \\
X6.3 & 32 & 3,00 & 5,00 & 4,2500 & 0,67202 & 0,452 \\
X10.5 & 32 & 3,00 & 5,00 & 4,2188 & 0,75067 & 0,564 \\
X10.4 & 32 & 3,00 & 5,00 & 4,2188 & 0,79248 & 0,628 \\
X5.2 & 32 & 3,00 & 5,00 & 4,1875 & 0,59229 & 0,351 \\
X7.4 & 32 & 3,00 & 5,00 & 4,1563 & 0,72332 & 0,523 \\
X5.1 & 32 & 3,00 & 5,00 & 4,1563 & 0,72332 & 0,523 \\
X5.4 & 32 & 3,00 & 5,00 & 4,1250 & 0,83280 & 0,694 \\
\hline
\end{tabular}

Based on the competency attributes used, it is found that the highest-ranking of competencies considered important by the employer is being able to apply relevant laws, regulations, and codes of conduct in work and decision making, and being able to contribute and participate in occupational health and safety management arrangements following the policy. and organizational procedures, as well as being able to record debt transfers to debit cards. The first and second attributes are generic skill attributes, while the third attribute is technical skills. So based on this, it can be seen that in the attribute generic skills are important for employers.

Table 5. Results of Skills Ranking by Alumni based on Mean

\begin{tabular}{lll}
\hline Variable & Skill Category & Mean \\
\hline X2 & Generic Skills & 4,4791 \\
X9 & Technical Skills & 4,3906 \\
X8 & Technical Skills & 4,3688 \\
X1 & Generic Skills & 4,3625 \\
X6 & Technical Skills & 4,3594 \\
X4 & Technical Skills & 4,3542 \\
X3 & Technical Skills & 4,3333 \\
X10 & Technical Skills & 4,3188 \\
X7 & Technical Skills & 4,3000 \\
X5 & Technical Skills & 4,1797 \\
\hline
\end{tabular}

Based on the table above the mean for all generic skills is 4,420 while the mean for technical skills is 4,325 . These results indicate that the average employer perceives that generic skills are more important than technical skills, this is supported by a significance value $(t=5.48$ and sig $=0.00)$ Thus, hypothesis 2 is supported. From these results, it can be seen that overall employers perceive that generic skills are more important than technical skills, although in terms of individually technical skills are still on the $1^{\text {st }}$ rank in the top ten of mean above 4.4. 


\section{Conclusion and Suggestion}

The results showed that alumni consider generic skills more important than technical skills as a whole, although individually, technical skills are considered more important than generic skills, this is evidenced by the highest mean score on technical skills according to alumni perceptions. The study also found that overall, employers also considered generic skills more important than technical skills even though individually technical skills obtained the highest mean score according to employer perceptions. This study has limitations, namely the lack of samples obtained from the employer (as many as 32 samples), this can be a consideration for further research so that the research results become better.

\section{References}

[1] Bowden, J., \& Masters, G. 1993. Implications for Higher Education of a Competency-Based Approach to Education and Training. Canberra: AGPS

[2] Braun, N.M. 2004. Critical Thinking in the Business Curriculum, Journal of Education for Business, Mar/Apr, Vol. 78, No. 4, pages. 232-236

[3] Crebert, R. G. 2002. Institutional Research into Generic Skills and Graduate Attributes:Constraints and Dilemmas, Higher Educational Research \& Development, 21 (1), page 121-135

[4] De Lange, P., Jackeling, B., \& Gut, A. 2006. Accounting Graduates' perceptions of skills emphasis in Australian undergraduate accounting courses: an investigation from two Victorian universities. Accounting and Finance, Vol. 46, pages. 365-386

[5] Holmes, L. 2001. Reconsidering graduate employability: The 'graduate identity' approach, Quality in Higher Education, 7 (2), 111-119

[6] Jackling, B. \& De Lange, P. 2009. Do accounting graduates' skills meet the expectations of employers? A matter of convergence or divergence. Accounting Education: An International Journal 18 (4/5), 369-85

[7] Kavanagh, M., \& Drennan, L. 2008. What skills and attributes does an accounting graduate need? Evidence from student perceptions and employer expectations. Accounting and Finance, 48, 279-300

[8] Klibi, Mohamed Faker dan Ahmed Attef Oussii. 2013. Skills and Attributes Needed for Success in Accounting Career: Do Employers' Expectations Fit with Students' Perceptions? Evidence from Tunisia. International Journal of Business and Management; Vol. 8, No. 8, pages $118-132$

[9] Sithole, M. 2015. Quality in accounting graduates: Employer expectations of the graduate skills in the Bachelor of Accounting degree. European Scientific Journal, 11(22), 165-180

[10] Utama, Angela Ria Karunia Putri. 2017. Gap Analysis of Competency Accounting Graduates with Employer Expectations. Faculty of Economics and Business, Soegijapranata Catholic University. Semarang 